\title{
Influence of Lime and Phosphorus Application Rates on Growth of Maize in an Acid Soil
}

\author{
Peter Asbon Opala \\ Department of Soil Science, Maseno University, P.O. Box 3275-40100, Kisumu, Kenya \\ Correspondence should be addressed to Peter Asbon Opala; ptropala@yahoo.com
}

Received 24 October 2016; Revised 16 December 2016; Accepted 22 December 2016; Published 11 January 2017

Academic Editor: Tibor Janda

Copyright (C) 2017 Peter Asbon Opala. This is an open access article distributed under the Creative Commons Attribution License, which permits unrestricted use, distribution, and reproduction in any medium, provided the original work is properly cited.

The interactive effects of lime and phosphorus on maize growth in an acid soil were investigated in a greenhouse experiment. A completely randomized design with 12 treatments consisting of four lime levels, $0,2,10$, and $20 \mathrm{t} \mathrm{ha}^{-1}$, in a factorial combination with three phosphorus rates, 0,30 , and $100 \mathrm{~kg} \mathrm{ha}^{-1}$, was used. Maize was grown in pots for six weeks and its heights and dry matter yield were determined and soils were analyzed for available $\mathrm{P}$ and exchangeable acidity. Liming significantly reduced the exchangeable acidity in the soils. The effect of lime on available $\mathrm{P}$ was not significant but available $\mathrm{P}$ increased with increasing $\mathrm{P}$ rates. There was a significant effect of lime, $\mathrm{P}$, and $\mathrm{P}$ by lime interactions on plant heights and dry matter. Without lime application, dry matter increased with increasing $\mathrm{P}$ rates but, with lime, dry mattes increased from 0 to $30 \mathrm{~kg} \mathrm{Pha}^{-1}$ but declined from 30 to $100 \mathrm{~kg} \mathrm{P}^{-1}$. The highest dry matter yield $\left(13.8 \mathrm{~g} \mathrm{pot}^{-1}\right)$ was obtained with a combined $2 \mathrm{tha}^{-1}$ of lime with $30 \mathrm{~kg} \mathrm{Pha}^{-1}$ suggesting that lime application at low rates combined with moderate amounts of $\mathrm{P}$ would be appropriate in this soil.

\section{Introduction}

The problem of acid soil infertility in the tropics has been recognized for a long time $[1,2]$. In acid soils with $\mathrm{pH}<$ 5.5 , the solubility of aluminium increases to toxic levels that severely restrict root systems and reduce plant growth $[3,4]$. In addition, phosphorus reacts with iron and aluminium in soil solution under acidic conditions to form insoluble phosphates hence reducing its availability to plants [5]. Phosphorus deficiency often, therefore, occurs simultaneously with aluminium toxicity in these soils [6]. Efforts to ameliorate the deleterious effects of soil acidity must therefore be accompanied by measures to increase available phosphorus in soils.

Addition of lime to agricultural acid soils has been widely adopted as an amelioration strategy for many years as a means of improving crop production $[7,8]$ but is rarely used in western Kenya. Failure to use lime, together with the increased use of acidifying fertilizers such as urea and diammonium phosphate, which are used to correct $\mathrm{N}$ and $\mathrm{P}$ deficiencies, has resulted in a marked increase in acidity of many of these soils [9]. Changes in soil $\mathrm{pH}$ brought about by liming may have profound effects on the availability of many elements absorbed by crops. Liming increases soil $\mathrm{pH}$ and therefore eliminates aluminium toxicity at $\mathrm{pH}>5.5$ by precipitating $\mathrm{Al}$ thus making it unavailable for plant uptake [10]. It also improves Ca supply and Mo availability and ensures optimal bacterial nitrogen fixation [11]. But its effect on availability of $\mathrm{P}$ is controversial [12].

Conflicting reports suggest that the prior liming of highly weathered acid soils can result in an increase, a decrease, or no change in the availability of applied phosphate. These effects appear to be dependent on the rates of lime and P fertilizer applied and their interactions [13]. For example, at high lime rates, the soil $\mathrm{pH}$ increases to $>6$ and the soluble $\mathrm{P}$ forms a complex with $\mathrm{Ca}$, and consequently $\mathrm{P}$ availability is decreased [14] while low lime rates are insufficient to eliminate soluble $\mathrm{Al}$ and $\mathrm{Fe}$ which fix $\mathrm{P}$ at low $\mathrm{pH}$. Appropriate combination of lime and $\mathrm{P}$ is therefore an important strategy for improving crop growth in acid soils [15]. There is however paucity of information on interactive effects of lime and phosphate fertilizers on crop performance in western Kenya and this limits the ability of farmers to make informed decisions on the appropriate rates of lime and P fertilizer to be combined. The objective of this study was therefore to investigate the interactive effects of lime and phosphate fertilizer on 
TABLE 1: Initial soil physical and chemical characteristics $(0-20 \mathrm{~cm})$ at Maseno University.

\begin{tabular}{lc}
\hline Soil parameter & Value \\
\hline $\mathrm{pH}\left(\mathrm{H}_{2} \mathrm{O}\right)$ & 5.3 \\
Exchangeable acidity & $0.4 \mathrm{cmol} \mathrm{kg}^{-1}$ \\
Total N & $2.0 \mathrm{~g} \mathrm{~kg}^{-1}$ \\
Organic C & $16.8 \mathrm{~g} \mathrm{~kg}^{-1}$ \\
Bicarbonate extractable P & $3.5 \mathrm{mg} \mathrm{kg}^{-1}$ \\
Exchangeable K & $0.3 \mathrm{cmol} \mathrm{kg}^{-1}$ \\
Exchangeable Ca & $4.2 \mathrm{cmol} \mathrm{kg}^{-1}$ \\
Exchangeable $\mathrm{Mg}$ & $1.4 \mathrm{cmol} \mathrm{kg}^{-1}$ \\
Clay & $36.5 \%$ \\
Sand & $42.2 \%$ \\
Silt & $21.3 \%$ \\
\hline
\end{tabular}

TABLE 2

\begin{tabular}{|c|c|}
\hline $\begin{array}{l}\text { Treatment } \\
\text { number }\end{array}$ & Treatment combinations \\
\hline 1. & 0 tha $^{-1}$ lime, $0 \mathrm{P} \mathrm{kg} \mathrm{ha}^{-1}$ \\
\hline 2. & 0 tha $^{-1}$ lime, $30 \mathrm{kgPha}^{-1}$ \\
\hline 3. & $0 \mathrm{t} \mathrm{ha}^{-1}$ lime, $100 \mathrm{~kg} \mathrm{Pha}^{-1}$ \\
\hline 4. & $2 \mathrm{tha}^{-1}$ lime, $0 \mathrm{~kg} \mathrm{Pha}^{-1}$ \\
\hline 5. & $2 \mathrm{tha}^{-1}$ lime, $30 \mathrm{~kg} \mathrm{Pha}^{-1}$ \\
\hline 6. & $2 \mathrm{tha}^{-1}$ lime, $100 \mathrm{~kg} \mathrm{Pha}^{-1}$ \\
\hline 7. & $10 \mathrm{tha}^{-1}$ lime, $0 \mathrm{~kg} \mathrm{P} \mathrm{ha}^{-1}$ \\
\hline 8. & $10 \mathrm{tha}^{-1}$ lime, $30 \mathrm{~kg} \mathrm{P} \mathrm{ha}^{-1}$ \\
\hline 9. & $10 \mathrm{tha}^{-1}$ lime, $100 \mathrm{~kg} \mathrm{Pha}^{-1}$ \\
\hline 10. & $20 \mathrm{tha}^{-1}$ lime, $0 \mathrm{P} \mathrm{kg} \mathrm{P} \mathrm{ha}^{-1}$ \\
\hline 11. & $20 \mathrm{tha}^{-1}$ lime, $30 \mathrm{P} \mathrm{kg} \mathrm{Pha}^{-1}$ \\
\hline 12. & $20 \mathrm{tha}^{-1}$ lime, $100 \mathrm{~kg} \mathrm{Pha}^{-1}$ \\
\hline
\end{tabular}

exchangeable acidity, $\mathrm{P}$ availability, and maize growth in an acid soil of western Kenya.

\section{Materials and Methods}

2.1. Experimental Site and Soil. A greenhouse pot experiment was conducted from March to April 2016 at Maseno University $\left(0^{\circ} 00^{\prime} 17.36^{\prime \prime} \mathrm{S}\right.$ and $\left.34^{\circ} 36^{\prime} 01.62^{\prime \prime} \mathrm{E}\right)$ in western Kenya. The soil used in the study was a Ferralsol whose initial properties were determined before the establishment of the experiment and are presented in Table 1 . The soil was generally well drained clay loam, acidic and low in available P.

2.2. Experimental Design and Management. The soil (0$20 \mathrm{~cm}$ ) used in the study was collected randomly from various spots at the Maseno University farm and bulked. It was airdried, sieved through a $4 \mathrm{~mm}$ mesh, and applied in all the pots at a rate $4 \mathrm{~kg}$ of soil pot ${ }^{-1}$. These pots consisted of the experimental units. There were twelve treatments consisting of four levels of lime $(0,2,10$, and 20 tons/ha) in a factorial combination with three rate of $\mathrm{P}\left(0,30\right.$, and $\left.100 \mathrm{~kg} \mathrm{Pha}^{-1}\right)$ (Table 2 ) replicated thrice in a completely randomized design.

A burnt lime material with $92.5 \%$ calcium carbonate $\left(\mathrm{CaCO}_{3}\right)$ equivalent and ground to pass through a $0.25 \mathrm{~mm}$ sieve was used in this study. Triple superphosphate $(46 \%$ $\mathrm{P}_{2} \mathrm{O}_{5}$ ) was used to supply P. Calcium ammonium nitrate and muriate of potash were applied to all the treatments at the rate of $60 \mathrm{~kg} \mathrm{ha}^{-1}$ to supply $\mathrm{N}$ and $\mathrm{K}$ which are often limiting in these soils. All the fertilizers and lime were incorporated and thoroughly mixed with the soil at the time of planting. Two maize seeds were planted per pot and later thinned to one at one week after emergence. Soil moisture content was maintained at around field capacity by regular watering.

2.3. Data Collection. Soil was sampled six weeks after planting (WAP) from each treatment and analyzed for exchangeable acidity and available phosphorus using standard procedures as described by [16]. Exchangeable acidity was extracted using unbuffered $1 \mathrm{M} \mathrm{KCl}$. In brief, $25 \mathrm{ml}$ of $1 \mathrm{M} \mathrm{KCl}$ was added to $10 \mathrm{~g}$ of air-dry soil and shaken for 10 minutes on a reciprocal shaker and then allowed to stand for 30 minutes. The contents were filtered and the soil leached with 5 successive $25 \mathrm{ml}$ aliquots of $1 \mathrm{M} \mathrm{KCl}$. The filtrate was titrated with $0.1 \mathrm{MNaOH}$ to determine the exchangeable acidity $\left(\mathrm{H}^{+}\right.$and $\left.\mathrm{Al}^{3+}\right)$ in the extract [16]. The available $\mathrm{P}$ was determined by the Olsen method [17] which has been reported to correlate well with maize yields in similar soils in western Kenya [18]. The method consisted of extracting soil $\mathrm{P}$ with $0.5 \mathrm{M} \mathrm{NaHCO}_{3}(\mathrm{pH} 8.5)$ using a soil extractant ratio of $1: 20$. The samples were shaken on a reciprocal shaker for 30 minutes and filtered through a Whatman number 5 filter paper and the $\mathrm{P}$ in the filtrate was determined colorimetrically at $880 \mathrm{~nm}$. Plant heights were determined at 4 and 6 WAP while the dry weight was determined after harvesting at 6 WAP by oven drying at $70^{\circ}$ Celsius to a constant weight.

2.4. Statistical Analysis. All the generated data were subjected to analysis of variance (ANOVA) using Genstat statistical program and the least significant difference between means (LSD) used to separate the treatment means at statistical significance level of $p \leq 0.05$.

\section{Results and Discussion}

3.1. Exchangeable Acidity. There was no significant interaction between lime and phosphorus application rates on exchangeable acidity (Table 3 ). The effect of phosphorus was also not significant. This is inconsistent with other studies that have reported that $\mathrm{P}$ can reduce exchangeable acidity by precipitating the $\mathrm{Al}$ in solution [19]. The rates of $\mathrm{P}$ used in such studies were however much higher than in the present study where the rates of $\mathrm{P}$ used are likely to have been too low to achieve this effect. Application of lime, irrespective of the rate used, significantly reduced the exchangeable acidity compared to the control. This is to be expected because lime is known to increase the soil $\mathrm{pH}$, hence precipitating $\mathrm{Al}$ as $\mathrm{Al}(\mathrm{OH})_{3}[20,21]$. This has the effect of reducing exchangeable acidity which comprises $\mathrm{Al}^{3+}$ and $\mathrm{H}^{+}$. However, exchangeable acidity among the lime treatments did not differ significantly. It is likely that all the $\mathrm{Al}$ was precipitated with application of lime, even at the lowest rate, and the exchangeable acidity that 
TABLE 3: Exchangeable acidity $\left(\mathrm{Cmolkg}^{-1}\right)$.

\begin{tabular}{|c|c|c|c|c|}
\hline \multirow{2}{*}{ Lime rate $t \mathrm{ha}^{-1}$} & \multicolumn{3}{|c|}{ Phosphorus rates $\mathrm{kg} \mathrm{ha}^{-1}$} & \multirow{2}{*}{ Means } \\
\hline & 0 & 30 & 100 & \\
\hline 0 & 0.42 & 0.38 & 0.43 & 0.41 \\
\hline 2 & 0.15 & 0.16 & 0.13 & 0.14 \\
\hline 10 & 0.14 & 0.12 & 0.12 & 0.13 \\
\hline 20 & 0.15 & 0.12 & 0.13 & 0.13 \\
\hline Means & 0.20 & 0.20 & 0.20 & 0.20 \\
\hline \multicolumn{5}{|c|}{ F probabilities for ANOVA for phosphorus and lime rates } \\
\hline Lime & & & $<0.001$ & \\
\hline Phosphorus & & & 0.873 & \\
\hline Lime $\times$ phosphorus & & & 0.996 & \\
\hline \multicolumn{5}{|l|}{ LSD } \\
\hline Lime & & & 0.0924 & \\
\hline Phosphorus & & & 0.0800 & \\
\hline Lime $\times$ phosphorus & & & 0.1600 & \\
\hline
\end{tabular}

TABle 4: Available phosphorus $\left(\mathrm{mg} \mathrm{kg}^{-1}\right)$.

\begin{tabular}{|c|c|c|c|c|}
\hline \multirow{2}{*}{ Lime rate $\mathrm{tha}^{-1}$} & \multicolumn{3}{|c|}{ Phosphorus rates $\mathrm{kg} \mathrm{ha}^{-1}$} & \multirow{2}{*}{ Means } \\
\hline & 0 & 30 & 100 & \\
\hline 0 & 3.70 & 4.11 & 8.78 & 5.53 \\
\hline 2 & 7.92 & 8.18 & 9.42 & 8.51 \\
\hline 10 & 3.36 & 6.49 & 13.77 & 7.87 \\
\hline 20 & 4.97 & 6.83 & 12.62 & 8.14 \\
\hline Means & 4.99 & 6.40 & 11.15 & 7.51 \\
\hline
\end{tabular}

F probabilities for ANOVA for phosphorus and lime rates

\begin{tabular}{lc}
\hline Lime & 0.239 \\
Phosphorus & $<0.001$ \\
Lime $\times$ phosphorus & 0.389 \\
\hline LSD & \\
Lime & 3.210 \\
Phosphorus & 2.780 \\
Lime $\times$ phosphorus & 5.561 \\
\hline
\end{tabular}

was measured was therefore due to only $\mathrm{H}^{+}$. Hence there may be no need to apply lime at rates higher than $2 \mathrm{tha}^{-1}$ in this soil.

3.2. Available Phosphorus. The available $\mathrm{P}$ ranged from 3.70 (control with no $\mathrm{P}$ and lime input) to $13.77 \mathrm{mg} \mathrm{kg}^{-1}\left(10 \mathrm{tha}^{-1}\right.$ of lime combined with $100 \mathrm{~kg} \mathrm{Pha}^{-1}$ ) (Table 4). There was no significant interaction between lime and phosphorus application rates on available $\mathrm{P}$. The effect of lime was also not significant but available $\mathrm{P}$ increased with increasing $\mathrm{P}$ rates for a given lime rate. Generally, the available P levels were low even after application of fertilizers and lime, therefore confirming that $\mathrm{P}$ was deficient in this soil and that some of the applied P could also have been fixed since most of the soils in western Kenya are known to have high $\mathrm{P}$ fixation capacities [22, 23]. It was only at high rates of $\mathrm{P}$ application
TABLE 5: Plant height $(\mathrm{cm})$ at four weeks after planting.

\begin{tabular}{|c|c|c|c|c|}
\hline \multirow{2}{*}{ Lime rate $\mathrm{tha}^{-1}$} & \multicolumn{3}{|c|}{ Phosphorus rates $\mathrm{kg} \mathrm{ha}^{-1}$} & \multirow{2}{*}{ Means } \\
\hline & 0 & 30 & 100 & \\
\hline 0 & 50.1 & 72.7 & 82.6 & 68.5 \\
\hline 2 & 79.3 & 92.1 & 51.9 & 74.4 \\
\hline 10 & 88.9 & 64.5 & 73.3 & 75.6 \\
\hline 20 & 61.0 & 68.3 & 67.9 & 65.7 \\
\hline Means & 68.5 & 74.4 & 68.9 & \\
\hline \multicolumn{5}{|c|}{ F probabilities for ANOVA for phosphorus and lime rates } \\
\hline Lime & & & 0.032 & \\
\hline Phosphorus & & & 0.188 & \\
\hline Lime $\times$ phosphorus & & & $<0.001$ & \\
\hline \multicolumn{5}{|l|}{ LSD } \\
\hline Lime & & & 7.39 & \\
\hline Phosphorus & & & 6.40 & \\
\hline Lime $\times$ phosphorus & & & 12.80 & \\
\hline
\end{tabular}

TABle 6: Plant height $(\mathrm{cm})$ at six weeks after planting.

\begin{tabular}{|c|c|c|c|c|}
\hline \multirow{2}{*}{ Lime rate $\mathrm{tha}^{-1}$} & \multicolumn{3}{|c|}{ Phosphorus rates $\mathrm{kg} \mathrm{ha}^{-1}$} & \multirow{2}{*}{ Means } \\
\hline & 0 & 30 & 100 & \\
\hline 0 & 63.3 & 95.6 & 103.1 & 87.4 \\
\hline 2 & 99.3 & 114.4 & 64.3 & 92.7 \\
\hline 10 & 110.1 & 83.6 & 95.6 & 96.4 \\
\hline 20 & 80.7 & 87.6 & 88.7 & 85.7 \\
\hline Means & 88.4 & 95.3 & 88.0 & 90.5 \\
\hline \multicolumn{5}{|c|}{ F probabilities for ANOVA for phosphorus and lime rates } \\
\hline Lime & & & 0.040 & \\
\hline Phosphorus & & & 0.068 & \\
\hline Lime $\times$ phosphorus & & & $<0.001$ & \\
\hline \multicolumn{5}{|l|}{ LSD } \\
\hline Lime & & & 8.00 & \\
\hline Phosphorus & & & 6.93 & \\
\hline Lime $\times$ phosphorus & & & 13.85 & \\
\hline
\end{tabular}

$\left(100 \mathrm{~kg} \mathrm{ha}^{-1}\right)$ with high lime rates of 10 or $20 \mathrm{tha}^{-1}$ that the available $\mathrm{P}$ exceeded the critical value of $10 \mathrm{mg} \mathrm{kg}^{-1}$ that has been reported to be adequate for maize production [24].

3.3. Plant Heights and Dry Weight. Plant heights at 4 WAP ranged from $50.1 \mathrm{~cm}$ (no lime, no $\mathrm{P}$ ) to $92.1 \mathrm{~cm}$ when $2 \mathrm{tha}^{-1}$ of lime was applied with $30 \mathrm{~kg} \mathrm{Pha}^{-1}$ (Table 5). There was a significant interaction between lime and P. When no lime was applied, plant heights increased with increasing $\mathrm{P}$ rates but when lime was applied, plant heights increased from 0 to $30 \mathrm{~kg} \mathrm{P} \mathrm{ha}{ }^{-1}$ but declined from 30 to $100 \mathrm{~kg} \mathrm{ha}^{-1} \mathrm{P}$. A similar trend in plant heights was observed at 6 WAP (Table 6).

The results of the effects of treatments on dry weight of maize plants are presented in Table 7. The effect of lime, P, and $\mathrm{P}$ by lime interactions on dry weight was significant. Averaged 
TABLE 7: Dry weight (grams pot ${ }^{-1}$ ).

\begin{tabular}{|c|c|c|c|c|}
\hline \multirow{2}{*}{ Lime rate $t \mathrm{ha}^{-1}$} & \multicolumn{3}{|c|}{ Phosphorus rates $\mathrm{kg} \mathrm{ha}^{-1}$} & \multirow{2}{*}{ Means } \\
\hline & 0 & 30 & 100 & \\
\hline 0 & 2.03 & 8.50 & 10.57 & 7.03 \\
\hline 2 & 9.73 & 13.17 & 3.87 & 8.92 \\
\hline 10 & 11.30 & 7.37 & 8.20 & 8.96 \\
\hline 20 & 3.64 & 7.73 & 7.13 & 6.17 \\
\hline Means & 6.68 & 9.19 & 7.44 & 7.77 \\
\hline \multicolumn{5}{|c|}{ F probabilities for ANOVA for phosphorus and lime rates } \\
\hline Lime & & & 0.001 & \\
\hline Phosphorus & & & 0.002 & \\
\hline Lime $\times$ phosphorus & & & $<0.001$ & \\
\hline \multicolumn{5}{|l|}{ LSD } \\
\hline Lime & & & 1.455 & \\
\hline Phosphorus & & & 1.260 & \\
\hline Lime $\times$ phosphorus & & & 2.521 & \\
\hline
\end{tabular}

across all lime rates, the highest dry matter yield was obtained with $30 \mathrm{~kg} \mathrm{P} \mathrm{ha}{ }^{-1}$ while averaged across all $\mathrm{P}$ rates the highest dry matter yield was obtained with $2 \mathrm{tha}^{-1}$ of lime. The trend in dry matter yield was similar to that of plant heights at 6 WAP whereby when no lime was applied dry matter increased with increasing $P$ rates but when lime was applied dry matter increased from 0 to $30 \mathrm{~kg} \mathrm{Pha}^{-1}$ but declined from 30 to $100 \mathrm{~kg} \mathrm{ha}^{-1} \mathrm{P}$. Application of lime at 10 and $20 \mathrm{tha}^{-1}$ could have resulted in overliming which has been reported to reduce crop yields due to lime induced $\mathrm{P}$ and micronutrient deficiencies $[15,25]$. In the present study, however, high rates of lime did not decrease the available P compared to control with no lime input and hence the likely cause of the low yields at high lime rates was micronutrient deficiencies. This is likely to have been exacerbated at high rates of $\mathrm{P}$ which have also been reported to aggravate $\mathrm{Zn}$ deficiencies in maize [26]. The observed increase in dry matter yield with increasing $\mathrm{P}$ rate, in treatments with no lime application, confirmed that $\mathrm{P}$ was limiting factor to maize growth in this soil. Similar responses to application of $\mathrm{P}$ fertilizers on P-deficient soils in western Kenya have been reported by other researchers [2729] thus making the region ideal for $P$ replenishment [22]. Aluminium toxicity is however not likely to have been a major problem because the exchangeable acidity of the soil was below the $1.00 \mathrm{cmolkg}^{-1}$ critical level for soils to have acidity problem according to [30]. The observed positive effect of lime on maize growth was therefore likely due to its effect in increasing the $\mathrm{pH}$ and therefore increasing availability of most nutrients to maize rather than its ability to ameliorate aluminium toxicity.

\section{Conclusions and Recommendations}

The exchangeable acidity levels in the soil were low and $\mathrm{Al}$ toxicity is therefore unlikely to be a major factor limiting maize growth in this soil. However, liming is likely to have increased the $\mathrm{pH}$ to levels conducive for availability of most nutrients and hence its positive effect on maize growth. The available $\mathrm{P}$ was also low and was likely a limiting factor for maize growth in this soil. The effect of lime, P, and P by lime interactions on dry weight was significant. The highest dry matter yield was obtained with $2 \mathrm{tha}^{-1}$ of lime applied with $30 \mathrm{~kg} \mathrm{Pha}{ }^{-1}$. The trend in dry matter yield was similar to that of plant heights whereby, when no lime was applied, dry matter increased with increasing $P$ rates but, when lime was applied, dry matter increased from 0 to $30 \mathrm{~kg} \mathrm{Pha}^{-1}$ but declined from 30 to $100 \mathrm{~kg} \mathrm{ha}^{-1} \mathrm{P}$. Lime application at low rates combined with moderate amounts of $\mathrm{P}$ is therefore recommended for soils in the study area.

\section{Competing Interests}

The author declares that there is no conflict of interests regarding the publication of this paper.

\section{Acknowledgments}

The author thanks Mercy Korir for the management of the experiment and data collection and Dickens Ondigo for assisting in soil analysis. The author is grateful to Maseno University for providing the greenhouse and laboratory facilities.

\section{References}

[1] P. A. Sanchez, Properties and Management of Soils in the Tropics, John Wiley \& Sons, New York, NY, USA, 1976.

[2] A. Wild, "Plant nutrients in soil: phosphate," in Russell's Soil Conditions and Plant Growth, A. Wild, Ed., pp. 695-742, John Wiley \& Sons, New York, NY, USA, 1988.

[3] H. Marschner, Mineral Nutrition of Higher Plants, Academic Press, London, UK, 1995.

[4] H. Matsumoto, "Cell biology of aluminium toxicity and tolerance in higher plants," International Review of Cytology, vol. 200, pp. 1-46, 2000.

[5] P. A. Sanchez and G. Uehara, "Management considerations for acid soils with high phosphorus fixation capacity," in The role of $P$ in agriculture, F. E. Khasawneh, C. R. Dinauer, E. C. Sample, and E. J. Kamprath, Eds., pp. 471-514, American Society of Agronomy, Madison, Wis, USA, 1980.

[6] H. Liao, H. Wan, J. Shaff, X. Wang, X. Yan, and L. V. Kochian, "Phosphorus and aluminum interactions in soybean in relation to aluminum tolerance. Exudation of specific organic acids from different regions of the intact root system," Plant Physiology, vol. 141, no. 2, pp. 674-684, 2006.

[7] R. J. Haynes, "Lime and phosphate in the soil-plant system," Advances in Agronomy, vol. 37, pp. 249-315, 1984.

[8] B. J. Scott, A. M. Ridley, and M. K. Conyers, "Management of soil acidity in long-term pastures of south-eastern Australia: a review," Australian Journal of Experimental Agriculture, vol. 40, no. 8, pp. 1173-1198, 2000.

[9] P. A. Opala, J. R. Okalebo, and C. Othieno, "Comparison of effects of phosphorus sources on soil acidity, available phosphorus and maize yields at two sites in western Kenya," Archives of Agronomy and Soil Science, vol. 59, no. 3, pp. 327339, 2013. 
[10] C. Meriño-Gergichevich, M. Alberdi, A. G. Ivanov, and M. Reyes-Díaz, "All ${ }^{3+}-\mathrm{Ca}^{2+}$ interaction in plants growing in acid soils: Al-phytotoxicity response to calcareous amendments," Journal of Soil Science and Plant Nutrition, vol. 10, no. 3, pp. 217$243,2010$.

[11] S. Bambara and P. A. Ndakidemi, "The potential roles of lime and molybdenum on the growth, nitrogen fixation and assimilation of metabolites in nodulated legume: a special reference to Phaseolus vulgaris L.," African Journal of Biotechnology, vol. 9, no. 17, pp. 2482-2489, 2010.

[12] R. J. Haynes, "Effects of liming on phosphate availability in acid soils," Plant and Soil, vol. 68, no. 3, pp. 289-308, 1982.

[13] M. E. Sumner and M. P. W. Farina, "Phosphorus interactions with other nutrients and lime in field cropping systems," in Advances in Soil Science, vol. 5, pp. 201-236, Springer, New York, NY, USA, 1986.

[14] N. K. Fageria, "Response of rice cultivars to liming in certado soil," Pesquisa Agropecuária Brasileira, Brasilia, vol. 19, pp. 883889, 1984.

[15] N. K. Fageria, F. J. P. Zimmermann, and V. C. Baligar, "Lime and phosphorus interactions on growth and nutrient uptake by upland rice, wheat, common bean, and corn in an Oxisol," Journal of Plant Nutrition, vol. 18, no. 11, pp. 2519-2532, 1995.

[16] J. M. Anderson and J. S. I. Ingram, Tropical Soil Biology and Fertility: A Handbook of Methods, CAB International, Wallingford, UK, 1993.

[17] S. R. Olsen, C. V. Cole, F. S. Watanabe, and L. A. Dean, "Estimation of available phosphorus in soils by extraction with sodium bicarbonate. USDA Agriculture, United States department of agriculture in cooperation with the Colorado agricultural experiment station," Circular, vol. 939, pp. 1-19, 1954.

[18] R. O. Nyambati and P. A. Opala, "The effect of minjingu phosphate rock and triple superphosphate on soil phosphorus fractions and maize yield in Western Kenya," ISRN Soil Science, vol. 2014, Article ID 920541, 8 pages, 2014.

[19] T. Iqbal, P. Sale, and C. Tang, "Phosphorus ameliorates aluminium toxicity of $\mathrm{Al}$ sensitive wheat seedlings," in Proceedings of the 19th World Congress of Soil Science, Soil Solutions for a Changing World, pp. 92-95, Brisbane, Australia, August 2010.

[20] N. V. Hue, "Responses of coffee seedlings to calcium and zinc amendments to two Hawaiian acid soils," Journal of Plant Nutrition, vol. 27, no. 2, pp. 261-274, 2004.

[21] E. F. Caires, I. C. Feldhaus, G. Barth, and F. J. Garbuio, "Lime and gypsum application on the wheat crop," Scientia Agricola, vol. 59, no. 2, pp. 357-364, 2002.

[22] G. Nziguheba, S. Zingore, J. Kihara et al., "Phosphorus in smallholder farming systems of sub-Saharan Africa: implications for agricultural intensification," Nutrient Cycling in Agroecosystems, vol. 104, no. 3, pp. 321-340, 2016.

[23] P. O. Kisinyo, C. O. Othieno, S. O. Gudu et al., "Immediate and residual effects of lime and phosphorus fertilizer on soil acidity and maize production in Western Kenya," Experimental Agriculture, vol. 50, no. 1, pp. 128-143, 2014.

[24] J. R. Okalebo, K. W. Gathua, and P. L. Woomer, Laboratory Methods of Soil and Plant Analysis. A Working Manual, TSBFCIAT, SACRED Africa, KARI, SSEA, Nairobi, Kenya, 2nd edition, 2002.

[25] D. K. Friesen, A. S. Juo, and M. H. Miller, "Liming and limephosphorus-zinc interactions in two nigerian ultisols: I. Interactions in the soill," Soil Science Society of America Journal, vol. 44 , no. 6 , p. $1221,1980$.
[26] S. Drissi, A. Houssa, A. Bamouh, J. Coquant, and M. Benbella, "Effect of zinc-phosphorus interaction on corn silage grown on sandy soil," Agriculture, vol. 5, no. 4, pp. 1047-1059, 2015.

[27] J. S. Ademba, J. K. Kwach, A. O. Esilaba, and S. M. Ngari, "The effects of phosphate fertilizers and manure on maize yields in South Western Kenya," East African Agricultural and Forestry Journal, vol. 81, no. 1, pp. 1-11, 2015.

[28] P. A. Opala, P. O. Kisinyo, and R. O. Nyambati, "Effects of Tithonia diversifolia, farmyard manure and urea, and phosphate fertiliser application methods on maize yields in western Kenya," Journal of Agriculture and Rural Development in the Tropics and Subtropics, vol. 116, no. 1, pp. 1-9, 2015.

[29] F. L. Ahmat, J. N. Mugwe, S. K. Kimani, and J. P. GweyiOnyango, "Maize response to Tithonia diversifolia and rock phosphate application under two maize cropping systems in Kenya," Journal of Applied Biosciences, vol. 79, pp. 6983-6991, 2014.

[30] A. Mohammed, A. U. Dikko, M. Audu, and T. Mohammed, "Effects of organic and inorganic soil amendments on soil reaction, exchangeable bases and cation exchange in sudan savanna soils of Nigeria," Nigerian Journal of Agriculture, Food and Environment, vol. 12, pp. 95-103, 2016. 


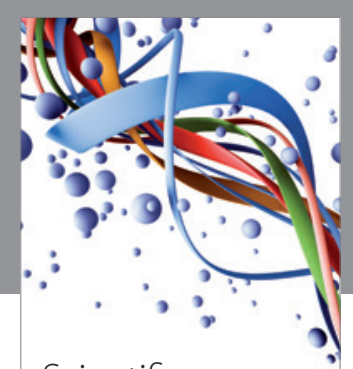

Scientifica
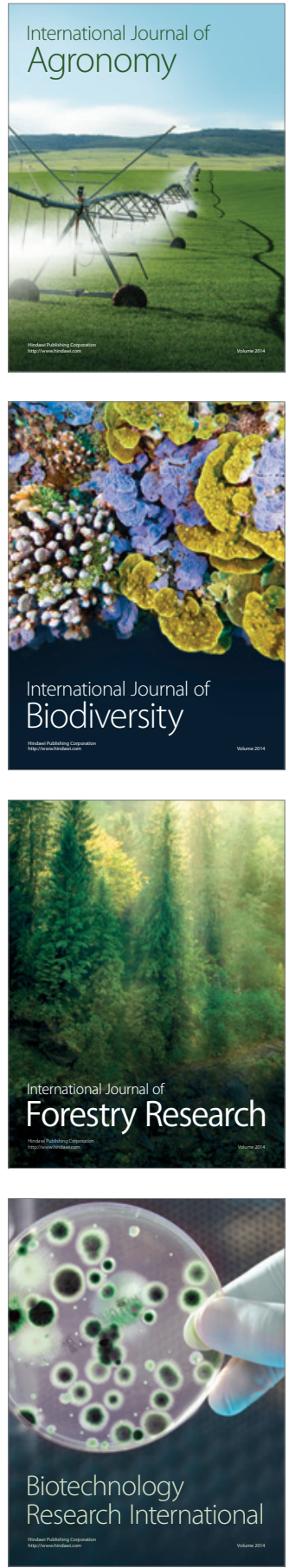
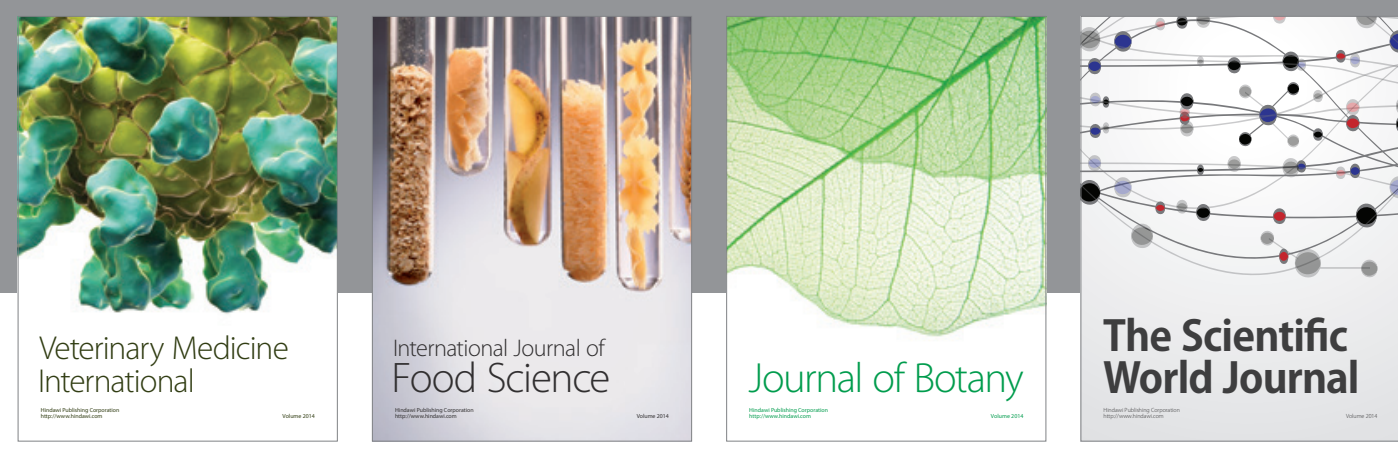

The Scientific

\section{World Journal}

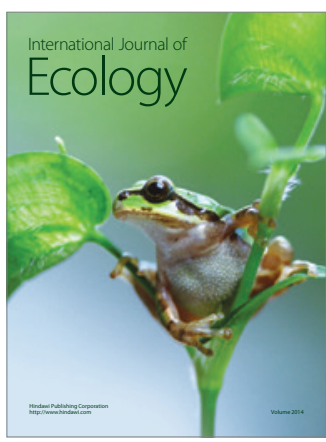

\section{Hindawi}

Submit your manuscripts at

https://www.hindawi.com
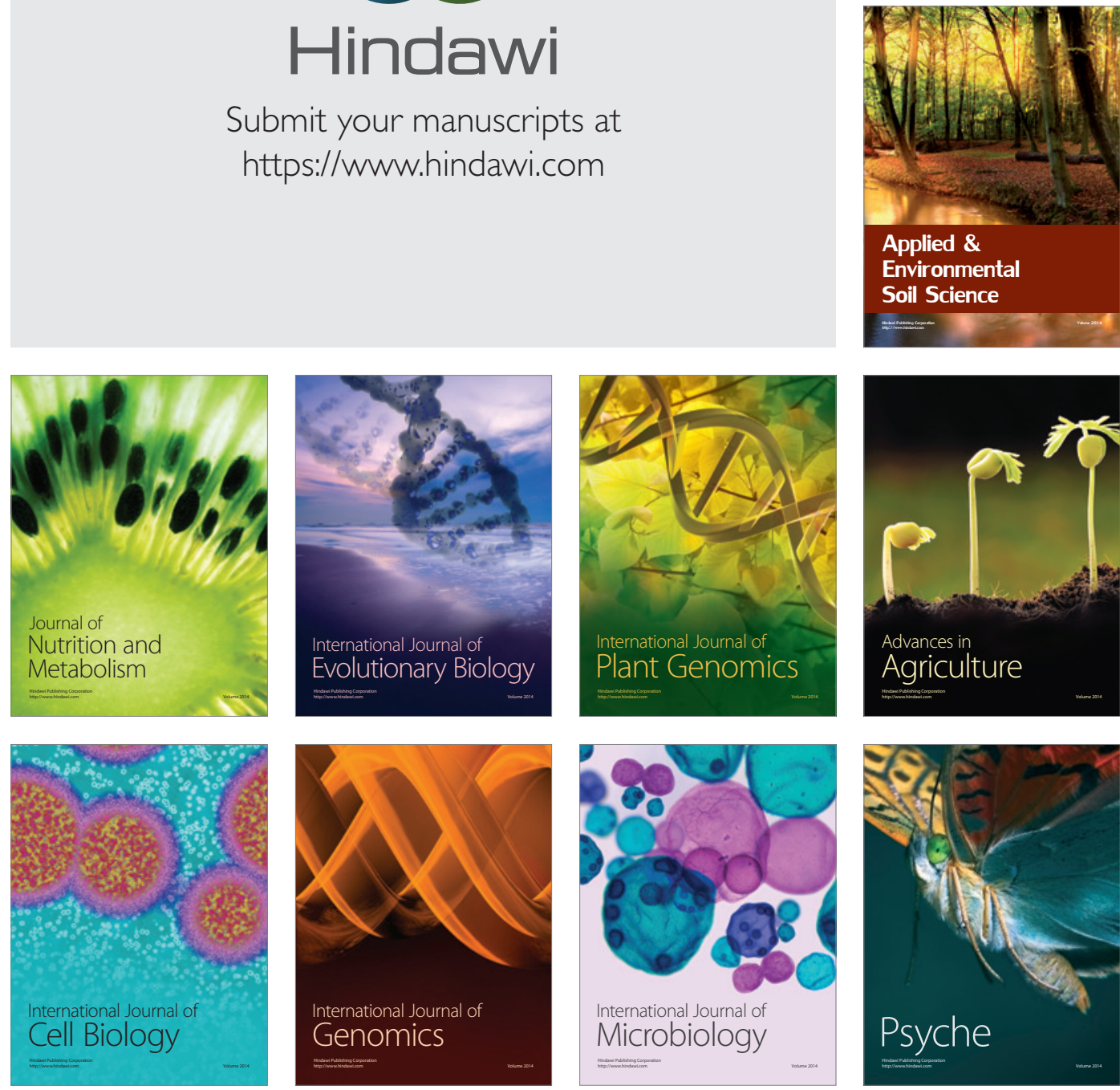
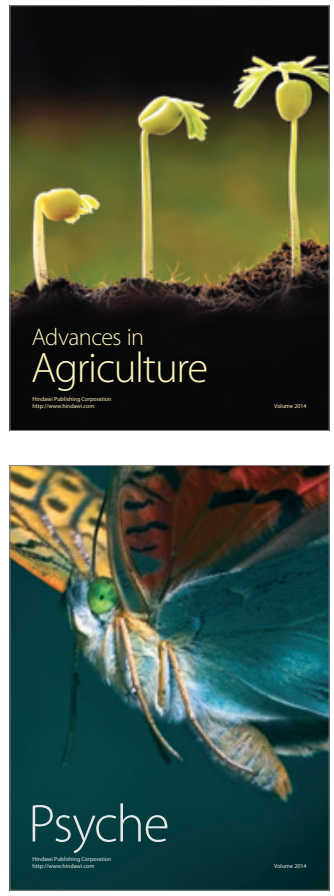